Bond University

Research Repository

\title{
A Lack of Knowledge and a Fear of Food Triggers Suffering in Patients with a History of Acute Diverticulitis: An Interpretative Phenomenological Analysis
}

Eberhardt, Fiona; Jenkins-Chapman, Julie; Nucera, Romina; Dalwood, Phoebe; Canavan, Russell; Marshall, Skye

Published in:

Clinical Nutrition

DOI:

10.1016/S0261-5614(19)32165-X

Licence:

CC BY-NC-ND

Link to output in Bond University research repository.

Recommended citation(APA):

Eberhardt, F., Jenkins-Chapman, J., Nucera, R., Dalwood, P., Canavan, R., \& Marshall, S. (2019). A Lack of Knowledge and a Fear of Food Triggers Suffering in Patients with a History of Acute Diverticulitis: An Interpretative Phenomenological Analysis. Clinical Nutrition, 38(S1), S180. [MON-PO330].

https://doi.org/10.1016/S0261-5614(19)32165-X

\section{General rights}

Copyright and moral rights for the publications made accessible in the public portal are retained by the authors and/or other copyright owners and it is a condition of accessing publications that users recognise and abide by the legal requirements associated with these rights.

For more information, or if you believe that this document breaches copyright, please contact the Bond University research repository coordinator. 


\section{Corrupted diet-disease knowledge and fear of food trigger suffering in patients with a history of acute diverticulitis}

\section{An interpretative phenomenological analysis}
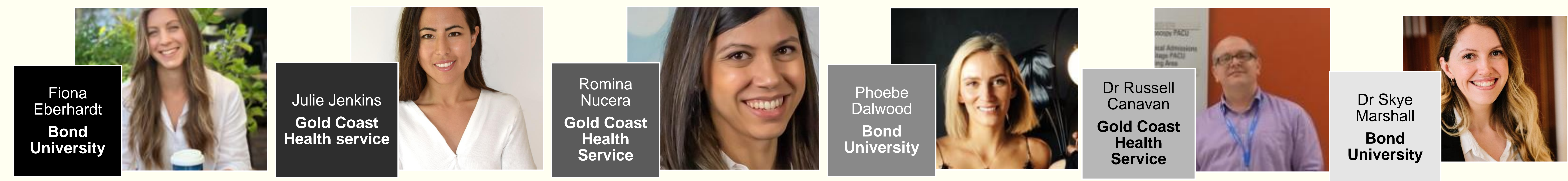

skye_marshall@bond.edu.au; @DrSkyeMarshall

\section{Introduction}

The inpatient dietary management for acute diverticulitis routinely includes dietary restrictions despite a lack of evidence for this approach.

The lack of qualitative research prevents understanding the patient experience, which is a barrier to providing patient-centred care.

\section{Findings}

Participants' described experiencing a phenomenon we have called the "fear of food framework"; which sits within a context of "corrupted diet-disease knowledge" and is triggered by a "fear of food".

\section{Cycle} recommences with increased fear of food “I'm more dubious [about food] now... l'm going to work harder"

A multidisciplinary collaborative approach is needed to avoid unnecessary dietary restrictions and negative food 